\title{
PUBLICZNOPRAWNY CHARAKTER ROSZCZEŃ ODSZKODOWAWCZYCH ZA WYWLASZCZENIE NIERUCHOMOŚCI
}

\section{WPROWADZENIE}

Pytanie, czy prawo do odszkodowania za wywłaszczenie nieruchomości jest prawem publicznym czy prywatnym, zadawał już Marian Zimmermann w monografii Polskie prawo wywłaszczeniowe ${ }^{1}$, na gruncie rozporządzenia Prezydenta Rzeczypospolitej z 24 września 1934 r. - Prawo o postępowaniu wywłaszczeniowem ${ }^{2}$. Profesor Zimmermann, opowiadając się za cywilnoprawnym charakterem przedmiotowych roszczeń na gruncie wspominanego wyżej rozporządzenia, oparł się na następujących kryteriach: (1) odrębności postępowania odszkodowawczego od postępowania administracyjnego w przedmiocie wywłaszczenia nieruchomości; (2) prowizorycznego charakteru orzeczenia władzy administracyjnej dotyczącego odszkodowania oraz (3) kompetencji sądów powszechnych do rozpatrywania spraw o odszkodowanie ${ }^{3}$. Przez prowizoryczność odszkodowania ustalonego w drodze administracyjnej M. Zimmermann rozumiał ewentualną tymczasowość decyzji administracyjnej w tym zakresie. Na gruncie Prawa o postępowaniu wywłaszczeniowem „przekazanie sprawy na drogę sądową nie jest bowiem odwołaniem - ale skierowaniem sprawy na właściwą drogę do właściwego sądu [...]"4. Postępowanie w przedmiocie odszkodowania za wywłaszczenie nieruchomości było dwuetapowe i gdyby wywłaszczany podmiot kwestionował orzeczenie administracyjne $\mathrm{w}$ tym przedmiocie, mógł wówczas, zgodnie z art. $40 § 2$ rozporządzenia, żądać ustalenia odszkodowania przez właściwy sąd powszechny. Zatem gdy kwestionowano orzeczenie organu administracji publicznej, to sąd powszechny ustalał, czy przysługuje odszkodowanie i w jakiej wysokości.

Jednocześnie M. Zimmermann jako kontrargument do swojej tezy przywołał stanowisko szwajcarskiego uczonego Fritza Fleinera, którego zdaniem „skoro każde odszkodowanie publiczno-prawne (powinno się tu mówić raczej o odszkodowaniu za szkody wyrządzone przez legalną działalność administra-

\footnotetext{
${ }^{1}$ M. Zimmermann, Polskie prawo wywtaszczeniowe, Lwów 1939.

${ }^{2}$ Rozporządzenie Prezydenta Rzeczypospolitej z 24 września 1934 r. - Prawo o postępowaniu wywłaszczeniowem (Dz. U. 1939, Nr 31, poz. 25 ze zm.).

${ }^{3}$ M. Zimmermann, op. cit., s. 178-179.

${ }^{4}$ Ibidem, s. 179.
} 
cji, względnie szkody wyrządzone na podstawie przepisów prawnych) pochodzi ze stosunku prawno-publicznego, to i samo roszczenie odszkodowawcze musi mieć ten charakter"'.

Obecnie kwestia charakteru roszczenia odszkodowawczego za wywłaszczenie nieruchomości nadal wywołuje kontrowersje w doktrynie i orzecznictwie. Jednoznaczne rozstrzygnięcie opisywanego problemu istotne jest w szczególności w kontekście zakreślenia terminu przedawnienia roszczeń odszkodowawczych. W prawie cywilnym zasadą jest, że uprawnienia majątkowe ulegaja przedawnieniu zgodnie $\mathrm{z}$ dyspozycją art. $117 \S 1$ k.c. W prawie publicznym natomiast uprawnienia majątkowe ulegaja przedawnieniu lub wygaśnięciu tylko wtedy, gdy zostało to wyraźnie określone przez ustawodawcę. Na gruncie prawa administracyjnego instytucja przedawnienia bowiem nie istnieje, chyba że na zasadzie ustawowego wyjątku ${ }^{6}$.

\section{CECHY PUBLICZNYCH PRAW PODMIOTOWYCH}

W Polsce charakter publicznych praw podmiotowych był przedmiotem szczególnie ożywionej dyskusji w dwudziestoleciu międzywojennym. W okresie Polski Ludowej (szczególnie w latach czterdziestych i pięćdziesiątych) konstrukcja publicznych praw podmiotowych była przedmiotem agresywnej krytyki. Współcześnie natomiast koncepcja publicznych praw podmiotowych jest uznawana za fundamentalną instytucję prawną demokratycznego państwa prawnego ${ }^{7}$.

Przepisy te chronia jednostki przed niezgodnymi z prawem działaniami organów administracji publicznej oraz stanowią podstawę żądań zachowania się zgodnego z przepisami ustaw, wysuwanych przez jednostki wobec organów administracji publicznej ${ }^{8}$. Innymi słowy, publiczne prawo podmiotowe oznacza sytuację podmiotu administrowanego, w której może on skutecznie domagać się od podmiotu administracji publicznej rozstrzygnięcia stwierdzającego, że jednostce w danych okolicznościach służy dane prawo podmiotowe publiczne oraz określone zostaną warunki jego wykonywania9

Prawa publiczne podmiotowe mają trójelementową strukturę, składają się mianowicie z podmiotu, adresata i przedmiotu ${ }^{10}$. Podmiotem jest każda osoba, która spełnia podmiotowe przesłanki określone w ustawie. Nie jest nim państwo ani jego organy, które w relacjach z jednostkami maja jedynie zobowiązania i kompetencje. Państwo lub jego organy są natomiast adresatem podmiotowych praw publicznych. Przedmiotem zaś podmiotowego prawa publicznego,

\footnotetext{
${ }^{5}$ Ibidem, s. 177.

${ }^{6}$ Z. Leoński, M. Szewczyk, M. Kruś, Prawo zagospodarowania przestrzeni, Warszawa 2012, s. 482

7 A. Wróbel, w: R. Hauser, Z. Niewiadomski, A. Wróbel, System prawa administracyjnego, t. 1: Instytucje prawa administracyjnego, Warszawa 2010, s. 350.

${ }^{8}$ Ibidem, s. 330.

9 Ibidem, s. 368.

${ }^{10}$ Ibidem, s. 374.
} 
rozumianego jako uprawnienie jednostki, jest zachowanie się (działanie lub zaniechanie) państwa lub jego organów ${ }^{11}$.

Według Wojciecha Jakimowicza treścia publicznego prawa podmiotowego jest możliwość skutecznego domagania się jednostki od państwa, rozumianego sensu largo, za pomoca zindywidualizowanego roszczenia ściśle określonego przez obowiązujace prawo zachowania się odpowiadajacego interesowi prawnemu żądajacego ${ }^{12}$. Roszczenie to zasadniczo różni się od roszczenia w prawie prywatnym. W prawie administracyjnym publicznoprawne roszczenie obywatela wobec państwa jest quasi-procesowym lub quasi-materialnym roszczeniem wobec państwa, przysługującym obywatelowi w celu ochrony jego gwarantowanego ustawą interesu prawnego ${ }^{13}$.

Podstawowym zadaniem publicznych praw podmiotowych jest łagodzenie nierównorzędności podmiotów stosunku administracyjnoprawnego (obywatela i organu administracji publicznej). W. Jakimowicz podkreśla jednocześnie, że aby publiczne prawa podmiotowe spełniały swój cel, muszą być expressis verbis zapisane w obowiązującym prawie - nie można ich zwłaszcza ujmować w sensie cywilnoprawnej zasady swobody kontraktowania ${ }^{14}$. Publiczne prawo podmiotowe stanowi zatem swoisty korelat obowiązków organu administracji publicznej o szczególnym znaczeniu zarówno dla ochrony interesów jednostki, jak i dla ochrony interesu publicznego, służą one bowiem kontroli działalności „władzy”"15.

Jednocześnie, zdaniem jednego z czołowych przedstawicieli nauki prawa administracyjnego i konstytucyjnego II Rzeczypospolitej - Stanisława Starzyńskiego, prawa publiczne podmiotowe nie przedawniaja się przez ich niewykonywanie i nie można się ich $\operatorname{zrzec}^{16}$. Jak słusznie wskazuje W. Jakimowicz, niedopuszczalność zrzekania się publicznych praw podmiotowych nie stoi na przeszkodzie temu, aby obywatel (zachowując swoje prawa podmiotowe) $\mathrm{z}$ nich nie korzystał ${ }^{17}$. Także Jan Boć podkreśla, że prawo administracyjne pozbawione jest jednoznacznej regulacji w zakresie dochodzenia wyrównania strat wynikłych z działań administracji publicznej w przypadku, gdy przepisy jednoznacznie nie wskazuja terminu do dochodzenia tego typu roszczeń. Autor zwraca uwagę, że na gruncie materialnego prawa administracyjnego nie istnieje zasada ogólna przewidująca przedawnienie roszczeń administracyjnoprawnych. Przy czym zdaniem J. Bocia, ewentualne przyjęcie, że w takim przypadku zastosowanie znajdujac przepisy prawa cywilnego, może zostać potraktowane jako nieuzasadnione ograniczenie uprawnienia podmiotu administrowanego do wyrównania szkód ${ }^{18}$. Powyższe cechy odróżniają bez wątpienia uprawnienia obywateli w prawie prywatnym od uprawnień w prawie publicznym.

11 Ibidem, s. 375 .

12 W. Jakimowicz, Publiczne prawa podmiotowe, Kraków 2002, s. 218.

${ }^{13}$ Ibidem, s. 222.

14 Ibidem, s. 239.

15 Ibidem, s. 241.

${ }^{16}$ S. Starzyński, Prawa i obowiazki obywatelskie, w: Z. Cybichowski, Encyklopedia podręczna prawa publicznego (konstytucyjnego, administracyjnego i międzynarodowego), t. 2: Państwo zwiazkowe - źródta lecznicze, Warszawa 1930, s. 681.

17 W. Jakimowicz, op. cit., s. 244.

18 J. Boć, op. cit., s. 143-145. 


\section{CECHY STOSUNKU ADMINISTRACYJNOPRAWNEGO}

Jak wyżej wykazano, nie ulega wątpliwości, że instytucja wywłaszczenia jest instytucja prawa administracyjnego, kreująca stosunek administracyjnoprawny między stronami. W literaturze, wskazując swoiste cechy stosunku administracyjnego, podkreśla się przede wszystkim szczegółowe elementy tego stosunku, mianowicie: przedmiot stosunku, podmioty stosunku, a także relacje między nimi.

W odniesieniu do przedmiotu stosunku administracyjnoprawnego, w literaturze wskazuje się, że musi on odpowiadać dwóm cechom: sprawa musi należeć do sfery działania administracji, a jednocześnie musi być dopuszczona do regulowania w trybie nakazów i zakazów administracyjnych, takich jak akty normatywne czy akty konkretyzujące prawo o indywidualnym charakterze. Co istotne, chociaż przedmiot stosunku administracyjnoprawnego mogą stanowić sytuacje bardzo zróżnicowane, za każdym razem wiąże się on jednak z władczymi lub niewładczymi formami administrowania w sferze tzw. administracji publicznej ${ }^{19}$.

Przyjmuje się, że jednym z podmiotów stosunku administracyjnoprawnego musi być organ reprezentujacy władztwo państwowe. Po drugiej stronie stosunku administracyjnoprawnego występuje natomiast podmiot administrowany, do którego kierowane sa zakazy i nakazy, np. obywatel.

Charakteryzujac swoiste cechy stosunku administracyjnoprawnego, powszechnie dokonuje się porównań stosunku administracyjnoprawnego ze stosunkiem cywilnoprawnym. W literaturze zwraca się uwagę, że może dojść do powstania stosunku administracyjnoprawnego z inicjatywy samego orga$\mathrm{nu}$, uprawnionego nota bene do orzekania i przesądzania o sytuacji drugiego z podmiotów. Jednocześnie doktryna zgodnie podkreśla, że fundamentalną cechą definiująca stosunek administracyjnoprawny jest nierówność stron. Nierówność ta wyraża się tym, że w ramach tego stosunku istnieje możliwość jednostronnego jego regulowania przez jedną ze stron - organ państwowy ${ }^{20}$.

Jan Zimmermann, wymieniając elementy definiujące stosunek administracyjnoprawny, zwraca uwagę na władztwo (przymus państwowy) sprawowane przez organy administracji publicznej wobec podmiotów administrowanych, a także jednostronność rozstrzygnięć i działań podejmowanych na podstawie norm prawa publicznego. Zdaniem J.Zimmermanna, organ administracji publicznej jest w ramach stosunku administracyjnoprawnego stroną uprzywilejowana - sam bowiem, bez udziału podmiotu administrowanego, formułuje treść nawiązywanego z nim stosunku. Chociaż zarówno nierównorzędność, jak i władztwo są stopniowalne - organ administracji publicznej, jako organ reprezentujący państwo, jest zawsze nośnikiem władztwa, a to, czy go używa, czy też nie, stosując daną formę działania, zależy już od jego szczegółowej kompetencji ${ }^{21}$.

\footnotetext{
19 R. Hauser, w: R. Hauser, Z. Niewiadomski, A. Wróbel, op. cit., s. 201-202.

20 Ibidem, s. 201.

21 J. Zimmermann, Aksjomaty prawa administracyjnego, Warszawa 2013, s. 141-144.
} 


\section{INSTYTUCJA WYWLASZCZENIA}

Obecnie, zgodnie z art. 21 ust. 2 Konstytucji Rzeczypospolitej Polskiej22 z 2 kwietnia 1997 r., wywłaszczenie jest dopuszczalne jedynie wówczas, gdy jest dokonywane na cele publiczne i za słusznym odszkodowaniem. Jednocześnie art. 64 ust. 3 Konstytucji stanowi, że „Własność może być ograniczona tylko w drodze ustawy i tylko w zakresie, w jakim nie narusza ona istoty prawa własności”. Z kolei zgodnie z art. 31 ust. 3 Konstytucji: „Ograniczenia w zakresie korzystania z konstytucyjnych wolności i praw mogą być ustanawiane tylko w ustawie i tylko wtedy, gdy są konieczne w demokratycznym państwie dla jego bezpieczeństwa lub porządku publicznego, bądź dla ochrony środowiska, zdrowia i moralności publicznej, albo wolności i praw innych osób. Ograniczenia te nie moga naruszać istoty praw".

W świetle wskazanych przepisów Konstytucji można stwierdzić, że instytucja wywłaszczenia polega na naruszeniu istoty danego prawa. W przypadku gdy do naruszenia istoty nie dochodzi, mamy do czynienia $\mathrm{z}$ ograniczeniem danego prawa w rozumieniu Konstytucji. Ponadto z przywołanych przepisów ustawy zasadniczej bezsprzecznie wynika, że aktualnie prawodawca kładzie szczególny nacisk na zakaz arbitralnego naruszania prawa własności, a wszelkie ewentualne jego ograniczenia muszą przybrać formę ustawowa. Co więcej - ograniczenia te moga być ustanawiane tylko i wyłącznie w interesie publicznym. Działanie w interesie publicznym wskazywane jest jednogłośnie przez doktrynę jako charakterystyczna cecha działań administracji publicznej ${ }^{23}$.

W art. 99 Konstytucji marcowej ${ }^{24}$ ustanowiona została konstytucyjna gwarancja ochrony mienia wszystkich mieszkańców, instytucji i społeczności przez Rzeczpospolita. Zgodnie z ww. przepisem zniesienie lub ograniczenie własności dopuszczalne było jedynie w przypadkach ustawa przewidzianych, ze względów wyższej użyteczności i za odszkodowaniem. 24 kwietnia 1935 r. została ogłoszona i jednocześnie weszła w życie Konstytucja kwietniowa ${ }^{25}$. Nie zawierała ona w ogóle rozdziału poświęconego prawom i obowiązkom obywateli, w tym przepisu, w którym expressis verbis zostałby sprecyzowany zakres ochrony prawa własności.

Przez termin „wywłaszczenie” na ogół rozumie się pozbawienie prawa własności nieruchomości na zasadzie jednostronnego kształtowania sytuacji prawnej drugiej strony stosunku prawnego przez podmiot administrujący. Powyższe jest o tyle słuszne, że definicję legalną przedmiotowego pojęcia obecnie odnajdujemy tylko w ustawie z 21 sierpnia $1997 \mathrm{r}$. o gospodarce nieruchomościami ${ }^{26}$ i odnosi się ona jedynie do nieruchomości. Zgodnie z art. 112 ust.

\footnotetext{
${ }^{22}$ Konstytucja Rzeczypospolitej Polskiej z 2 kwietnia 1997 r., Dz. U. 1997, Nr 78, poz. 483.

${ }^{23}$ J. Boć, Wyrównywanie strat wynikłych z legalnych działań administracji, Wrocław 1971, s. 48.

${ }^{24}$ Ustawa z 17 marca 1921 r. - Konstytucja Rzeczypospolitej Polskiej, Dz. U. 1921, Nr 44, poz. 267.

${ }^{25}$ Ustawa konstytucyjna z 23 kwietnia 1935 r., Dz. U. 1935, Nr 30, poz. 227.

${ }^{26}$ Ustawa z 21 sierpnia 1997 r. o gospodarce nieruchomościami, Dz. U. Nr 115, poz. 741 ze zm. (dalej jako: u.g.n.).
} 
2 u.g.n.: „wywłaszczenie nieruchomości polega na pozbawieniu albo ograniczeniu, w drodze decyzji, prawa własności, prawa użytkowania wieczystego lub innego prawa rzeczowego na nieruchomości”. Jednocześnie warto mieć na uwadze, że w okresie powojennym przedmiotem wywłaszczenia nierzadko stawały się również ruchomości i przedsiębiorstwa ${ }^{27}$.

Odebranie własności nieruchomości jest drastycznym przykładem wykonywania władzy publicznej, następuje bowiem w związku z wydaniem i uzyskaniem waloru ostateczności ${ }^{28}$ przez decyzję administracyjną o konstytutywnym charakterze. Instytucja wywłaszczenia jest bez wątpienia instytucja prawa administracyjnego - procedurę wywłaszczeniową może zainicjować wyłącznie państwo bądź też inny podmiot sprawujący administrację publiczną i posiadający związaną z tym władzę (np. jednostka samorządu terytorialnego) ${ }^{29} . \mathrm{Na}$ gruncie aktualnych regulacji prawnych stosownie do art. 113 ust. 1 u.g.n.: „nieruchomość może być wywłaszczona tylko na rzecz Skarbu Państwa albo na rzecz jednostki samorząu terytorialnego". Obowiązująca Konstytucja z 1997 r. wprowadziła rozwiązania wzorowane na tych istniejących w rozwiniętych demokracjach Europy Zachodniej. Doprowadziła też do stopniowego zmodyfikowania dominującego w okresie PRL spojrzenia na sytuację obywatela w państwie, „dotychczas postrzeganego wyłącznie jako podmiot podporządkowany scentralizowanej władzy, o ograniczonych uprawnieniach do sprawowania kontroli jej działań oraz niemający możliwości uczestniczenia w sprawowaniu władzy na poziomie lokalnym (we wspólnocie samorządowej)"30. Jednakże problematyka naprawiania skutków aktów przejęcia mienia na rzecz państwa w latach czterdziestych i pięćdziesiątych ubiegłego stulecia pozostaje nadal aktualna.

\section{SPECYFIKA PRAWA WŁASNOŚCI NOWEGO WŁAŚCICIELA}

Warto podkreślić, że specyficzny charakter ma samo prawo własności nieruchomości nabytej przez nowego właściciela na podstawie decyzji wywłaszczeniowej organu. Zachowanie prawa własności przez nowego właściciela uzależnione jest bowiem od realizacji publicznego celu, na jaki dana nieruchomość została wywłaszczona. Jeżeli nowy właściciel nie będzie realizować celu, na jaki uzyskał własność danej nieruchomości, to własność ta może mu zostać odebrana na mocy decyzji organu w postępowaniu o zwrot wywłaszczonej nieruchomości, wszczętym na wniosek poprzedniego właściciela (art. $136 \mathrm{i}$ n. u.g.n.). Jest to odstępstwo od ogólnej reguły nabywania prawa własności,

\footnotetext{
${ }^{27}$ A. Hetko, Dekret Warszawski. Wybrane aspekty systemowe, Warszawa 2012, s. 1.

${ }^{28}$ Art. 9 u.g.n. przewiduje obligatoryjne wstrzymanie wykonania zaskarżonej do sądu decyzji wywłaszczeniowej, można więc stwierdzić, że jej wykonanie wymaga, aby stała się prawomocna.

${ }^{29}$ A. Hetko, op. cit., s. 1-2.

${ }^{30}$ E. Lemańska, Przedawnienie roszczeń zwiazanych z wywłaszczaniem nieruchomości, Warszawa 2014, s. 14.
} 
które to zgodnie z art. 157 § 1 k.c. nie może być przeniesione pod warunkiem ani z zastrzeżeniem terminu.

W konsekwencji nasuwa się wniosek, że treść prawa własności uzyskanego przez nowego właściciela rzeczy jest dużo węższa niż jej dotychczasowego właściciela, a jego granice konstytuuje decyzja o wywłaszczeniu nieruchomości. Nowy właściciel może jedynie wykorzystywać daną nieruchomość do realizacji konkretnego celu publicznego wskazanego w decyzji administracyjnej pod rygorem zwrotu rzeczy jej dotychczasowemu właścicielowi.

\section{PRZEDAWNIENIE ROSZCZENIA O ODSZKODOWANIE NA PODSTAWIE ROZPORZAৃDZENIA PRAWO O POSTĘPOWANIU WYWŁASZCZENIOWEM Z 1934 R.}

Rozporządzenie z 1934 r. nie przewidywało terminu końcowego na wniesienie wniosku o odszkodowanie za wywłaszczone nieruchomości, nie wskazywało też terminu przedawnienia tego rodzaju roszczeń. W literaturze z lat trzydziestych ubiegłego wieku, m.in. w Komentarzu Feliksa Zadrowskiego do rozporządzenia Prawo o postępowaniu wywłaszczeniowem, podkreślano, że intencja ustawodawcy było postawienie wywłaszczonego w roli aktywnej, którego prawem (a nie obowiązkiem) było zgłoszenie wniosku do wojewody o określenie odszkodowania. Uprawnienie wywłaszczonego do złożenia wniosku do wojewody o ustalenie odszkodowania, którego termin oznaczono w rozporządzeniu jedynie a quo i nie oznaczono ad quem, upadało dopiero z chwila, gdy wywłaszczający (organ administracji publicznej) w sposób wyraźny zrzekł się wywłaszczenia ${ }^{31}$. Wówczas, zgodnie z art. 43 § 2 Prawa o postępowaniu wywłaszczeniowem, dotychczasowy właściciel mógł dochodzić bądź szkody, poniesionej przez niego wskutek postępowania wywłaszczeniowego, bądź tė̇ żądać zapłaty ustalonego odszkodowania w zamian za odstapienie nieruchomości.

Jednocześnie należy podkreślić, że na gruncie Prawa o postępowaniu wywłaszczeniowem z 1934 r. całe postępowanie wywłaszczeniowe należało $\mathrm{w}$ naszym ustawodawstwie do gałęzi prawa publicznego ${ }^{32}$. Odszkodowanie za wywłaszczenie na zasadach przewidzianych w rozporządzeniu miało być uprzednie, zupełne i pieniężne. Oznacza to, że objęcie własności rzeczy wywłaszczonej zależne miało być od uprzedniego wypłacenia sumy szacunkowej, ustalonej przez władzę tak, żeby wyrównywała wszelką i całą szkodę poniesioną skutkiem wywłaszczenia przez ekspropriata ${ }^{33}$.

Jaki zatem charakter miało roszczenie o odszkodowanie na podstawie rozporządzenia Prawo o postępowaniu wywłaszczeniowem? Sąd Najwyższy ${ }^{34}$

${ }^{31}$ F. Zadrowski, Prawo o postepowaniu wywłaszczeniowem. Komentarz, Warszawa 1935, s. 38-39.

${ }^{32}$ M. Zimmermann, op. cit., s. 177-180.

33 Ibidem, s. 17.

${ }^{34}$ Orzeczenie SN z 7 maja 1960 r., III CR 812/59, niepubl. 
opowiedział się za administracyjnoprawnym charakterem roszczenia odszkodowawczego na gruncie dekretu z $1949 \mathrm{r} \cdot{ }^{35}$, odsyłającego do rozporządzenia z 1934 r. w zakresie dochodzenia odszkodowania za wywłaszczenie nieruchomości. Sąd Najwyższy uzasadnił swoje stanowisko przez wskazanie, że wywłaszczenie nastapiło na rzecz Państwa, a do jego dochodzenia wskazano tryb administracyjnoprawny.

Jak wskazano na wstępie, M. Zimmermann, opowiadając się za prywatnoprawnym charakterem postępowania o ustalenie odszkodowania, oparł się na trzech argumentach: odrębności postępowania odszkodowawczego, prowizorycznego charakteru orzeczenia władzy administracyjnej oraz kompetencji sądów powszechnych do ustalania odszkodowania. Warto jednakże zauważyć, że odrębny tryb dochodzenia roszczeń o odszkodowanie obowiązuje także obecnie, co nie wpływa na stanowisko sądów administracyjnych o publicznoprawnym charakterze roszczenia. Odnośnie do prowizoryczności - aktualnie ona nie występuje, gdyż to nie sąd, lecz organ administracji publicznej w decyzji ustala wysokość odszkodowania. Co więcej, sąd (nota bene nie powszechny, lecz administracyjny) kontroluje jedynie legalność decyzji, nie może zaś orzec co do istoty sprawy. Sąd administracyjny, w przypadku stwierdzenia nieprawidłowości, może bowiem uchylić decyzję organu i przekazać sprawę organowi do ponownego rozpoznania. Czy owa prowizoryczność determinowała więc charakter roszczenia?

Zdaniem autora niniejszego artykułu kompetencja sądów powszechnych do rozpatrywania spraw o odszkodowanie przewidziana $\mathrm{w}$ rozporządzeniu z 1934 r. nie zmienia charakteru samego roszczenia. Prawodawca mógł bowiem zdecydować, że to sąd powszechny ustala wysokość odszkodowania, zwłaszcza że ówczesne sądownictwo administracyjne było słabo rozwinięte. Władza może się wszak ograniczyć.

\section{PRZEDAWNIENIE ROSZCZENIA O ODSZKODOWANIE NA PODSTAWIE DEKRETÓW Z LAT CZTERDZIESTYCH}

Przykładem aktu wywłaszczeniowego z lat czterdziestych jest dekret z 1948 r. o wywłaszczeniu majątków zajętych na cele użyteczności publicznej w okresie wojny $1939-1945^{36}$. Nie regulował on kompleksowo kwestii postępowania wywłaszczeniowego i w znaczącej mierze odsyłał w tym zakresie do rozporządzenia z $1934 \mathrm{r}$. Także dekret o nabywaniu i przekazywaniu nieruchomości niezbędnych dla realizacji narodowych planów gospodarczych z 1949 r. nie przewidywał ani terminu końcowego na wniesienie wniosku o odszkodowanie za wywłaszczone nieruchomości, ani terminu przedawnienia tego rodzaju roszczeń.

${ }^{35}$ Dekret z 26 kwietnia 1949 r. o nabywaniu i przekazywaniu nieruchomości niezbędnych dla realizacji narodowych planów gospodarczych, Dz. U. Nr 27, poz. 197 ze zm.

${ }^{36}$ Dekret z 7 kwietnia 1948 r. o wywłaszczeniu majątków zajętych na cele użyteczności publicznej w okresie wojny 1939-1945 r., Dz. U. Nr 20, poz. 138 ze zm. 
Ustawa nowelizująca ${ }^{37}$ dekret z 1949 r. weszła w życie 31 stycznia 1952 r. Odnosiła się także do dekretu z 1948 r., jednakże tylko w części. Ustawa nowelizująca wprowadzała 3-letni termin przedawnienia dla roszczeń odszkodowawczych za wywłaszczone nieruchomości, artykuł 7 ust. 1 ustawy nowelizującej stanowił zaś, że postępowania z wniosku o ustalenie odszkodowania, niezakończone ostatecznie w dniu wejścia w życie przedmiotowej ustawy, będą dalej prowadzone na podstawie przepisów dekretu z 1949 r. Przepis ten miał więc zastosowanie tylko do spraw, które były w toku w dniu jego wejścia w życie.

\section{PRZEDAWNIENIE ROSZCZEŃ ODSZKODOWAWCZYCH NA PODSTAWIE USTAWY Z 1958 R. I U.G.G.}

Zarówno ustawa z 1958 r., jak i uchylająca ją u.g.g. ${ }^{38}$ nie zawierały regulacji w zakresie terminów przedawnienia roszczeń o odszkodowanie za wywłaszczenie nieruchomości.

W obu wyżej wymienionych ustawach znajdowały się jedynie przepisy stricte intertemporalne dotyczące postępowań odszkodowawczych wszczętych, lecz jeszcze niezakończonych. Ustawy te nie zawierały jednak żadnych przepisów regulujacych sytuację, w której postępowanie wywłaszczeniowe zostało zakończone, a postępowanie w sprawie odszkodowania nigdy nie zostało wszczęte.

Ponadto ustawa z 1958 r. nie przewidywała wygaśnięcia czy przedawnienia roszczeń odszkodowawczych za wywłaszczenie nieruchomości. Natomiast zgodnie z dyspozycją art. 89 u.g.g. uległy wygaśnięciu prawa do odszkodowania za przejęte przez Państwo grunty, budynki i inne części składowe nieruchomości, przewidziane w art. 7 ust. 4 i 5 i art. 8 dekretu o własności i użytkowaniu gruntów na obszarze m. st. Warszawy ${ }^{39}$. Wynika z tego, że ustawodawca zna praktykę wygaszania roszczeń odszkodowawczych, jednak nie zastosował jej do roszczeń wynikajacych np. z dekretu z 1948 r.

Ustawa o gospodarce gruntami i wywłaszczaniu nieruchomości została uchylona przez u.g.n.

\section{ADMINISTRACYJNOPRAWNY CHARAKTER ROSZCZEŃ ODSZKODOWAWCZYCH NA GRUNCIE U.G.N.}

W doktrynie zgodnie przyjmuje się, że odebranie prawa własności dotychczasowemu właścicielowi na podstawie decyzji administracyjnej kreuje stosunek administracyjnoprawny oparty na zasadzie nierównorzędności stron.

\footnotetext{
${ }^{37}$ Ustawa z 29 grudnia 1951 r. zmieniająca dekret z 26 kwietnia 1949 r. o nabywaniu i przekazywaniu nieruchomości niezbędnych dla realizacji narodowych planów gospodarczych, Dz. U. Nr 4, poz. 25 ze zm.

${ }^{38}$ Ustawa z 29 kwietnia 1985 r. o gospodarce gruntami i wywłaszczaniu nieruchomości, Dz. U. 1985, Nr 22 poz. 99 (dalej jako: u.g.g.).

${ }^{39}$ Dekret z 26 października 1945 r. o własności i użytkowaniu gruntów na obszarze m. st. Warszawy, Dz. U. 1997, Nr 50, poz. 279 ze zm.
} 
Różnie interpretowany jest natomiast charakter odszkodowania należnego za odjęcie w sposób władczy prawa własności nieruchomości. Zdaniem Elżbiety Lemańskiej w stosunku roszczenia o ustalenie odszkodowania (niejako w opozycji do stosunku wywłaszczania) zachodzi cywilistyczna relacja materialnoprawna oparta na zasadzie równorzędności stron pomiędzy podmiotem wywłaszczanym a nowym właścicielem. W stosunku tym, zdaniem autorki, nie uczestniczy organ ${ }^{40}$, a jego źródłem nie jest decyzja administracyjna, ale art. 21 ust. 2 Konstytucji oraz art. 128 ust. 1 u.g.n. W braku kompleksowego uregulowania majątkowej odpowiedzialności odszkodowawczej za szkody wywołane legalnymi działaniami organów administracji publicznej - konieczne jest zaś sięganie do reguł cywilistycznych ${ }^{41}$.

Wydaje się jednak, że na gruncie u.g.n. instytucja wywłaszczenia składa się z trzech stadiów: wywłaszczania, ustalenia odszkodowania oraz samego wypłacenia odszkodowania. W polskim systemie prawnym ustawodawca bowiem przewidział, że odszkodowanie ustala starosta bądź w samej decyzji o wywłaszczeniu, bądź też w decyzji odrębnej (np. w przypadku wywłaszczenia działek gruntu pod drogi publiczne na podstawie decyzji o zezwoleniu na realizację inwestycji drogowej ${ }^{42}$ ).

Jednocześnie warto zwrócić uwagę, że konstytucyjne stuszne odszkodowanie, którego wypłacenie podmiotowi wywłaszczanemu jest obecnie conditio sine qua non procedury wywłaszczenia, zgodnie z art. 132 ust. 5 u.g.n. wypłaca starosta, jeżeli wywłaszczenie następuje na rzecz Skarbu Państwa, albo organ wykonawczy jednostki samorządu terytorialnego, jeżeli wywłaszczenie następuje na rzecz tej jednostki. Odszkodowanie zatem obciąża budżet beneficjenta wywłaszczenia. Można zastanowić się zatem, jaki charakter będzie mieć samo roszczenie o zapłatę odszkodowania w ustalonej wysokości oraz czy powyższe ma wpływ na charakter roszczenia o przyznanie odszkodowania i ustalenie jego wysokości. Wydaje się, że roszczenie to może mieć charakter cywilny, jednakże nie będzie to rzutowało na ocenę charakteru roszczenia związanego z ustaleniem odszkodowania. Wyróżnienie tego roszczenia ma jednak ten sens, że tylko w tym przypadku dochodzi do bezpośredniej relacji między podmiotem wywłaszczanym, a beneficjentem. W przypadku decyzji wywłaszczającej i ustalającej odszkodowanie występuje relacja na linii organ administracji publicznej a podmiot wywłaszczany albo też beneficjent (który wnioskuje do organu o wszczęcie postępowania). To również pokazuje, że roszczenie o ustalenie odszkodowania nie ma charakteru prywatnoprawnego, gdyż nie jest adresowane - by tak rzec - do podmiotu prywatnego.

Kwestia stosowania przepisów Kodeksu cywilnego o przedawnieniu w sprawach o odszkodowanie za nieruchomości przejęte na własność państwa wywołuje kontrowersje w doktrynie. Za cywilnoprawnym charakterem

40 E. Lemańska, Przedawnienie roszczenia o odszkodowanie za wywłaszczenie nieruchomości, „Państwo i Prawo” 2009, z. 10, s. 84.

41 Ibidem, s. 84.

42 Art. $11 \mathrm{f}$ ust. 1 pkt 6 ustawy o szczególnych zasadach przygotowania i realizacji inwestycji w zakresie dróg publicznych z 10 kwietnia 2003 r., Dz. U. 2013, poz. 687. 
roszczenia o odszkodowanie za wywłaszczenie nieruchomości opowiadają się m.in. Tadeusz Woś oraz Elżbieta Lemańska ${ }^{43}$. Jednakże w orzecznictwie Naczelnego Sądu Administracyjnego dość wyraźnie prezentuje się odmienny pogląd, że odszkodowanie należne za odebrane w sposób władczy nieruchomości nie ma charakteru cywilnoprawnego, lecz publicznoprawny, ponieważ jest ono akcesoryjne wobec odebrania prawa własności. Oznaczałoby to, że do roszczeń o odszkodowanie za wywłaszczenie nieruchomości nie mają zastosowania przepisy Kodeksu cywilnego o przedawnieniu roszczeń. „W razie przejęcia własności nieruchomości na rzecz państwa w drodze władczej, organ ma obowiązek z urzędu wydać decyzję o odszkodowaniu, chyba że ustawa stanowi inaczej" 44 .

Zdaniem Naczelnego Sądu Administracyjnego nie można przyjaćc, aby strony uzgadniające wysokość odszkodowania pozostawały w stosunku równorzędności wpływu na całość stosunku prawnego, a więc i także na zaistnienie skutku prawnego, na tle którego powstało uprawnienie odszkodowawcze. „Brak takiej równorzędności przejawia się z całą mocą w przypadku, gdy strony nie uzgodnią wysokości odszkodowania, ponieważ ustalenia odszkodowania dokonuje wtedy starosta, jako organ administracji publicznej w sposób władczy poprzez wydanie w tym zakresie decyzji administracyjnej" ${ }^{45}$. Stanowisko powyższe potwierdza także Marek Szewczyk, którego zdaniem nie może być mowy o jakiejkolwiek równorzędności podmiotów uczestniczących w stosunkach prawnych, jakie nawiąują się na podstawie omawianych przepisów u.g.n., ani o ich cywilnoprawnym charakterze ${ }^{46}$.

W związku z powyższym konsekwencja tezy o publicznoprawnym charakterze roszczenia o odszkodowanie $\mathrm{z}$ powodu wywłaszczenia nieruchomości jest fakt, że roszczenie takie - po pierwsze - nie ulega przedawnieniu, chyba że ustawa stanowi inaczej, po drugie zaś - roszczenia takiego nie można się $\operatorname{zrzec}^{47}$.

\section{DOCHODZENIE ROSZCZEŃ O ODSZKODOWANIE ZA WYWŁASZCZENIE DOKONANE PRZED WEJŚCIEM W ŻYCIE U.G.N.}

Ustawa o gospodarce nieruchomościami nie przewiduje wygaśnięcia czy przedawnienia roszczeń o odszkodowanie. Wręcz przeciwnie, zgodnie z art. 129 ust. 1 u.g.n.:

Odszkodowanie ustala starosta, wykonujący zadanie z zakresu administracji rządowej, w decyzji o wywłaszczeniu nieruchomości, z zastrzeżeniem ust. 5.

\footnotetext{
${ }^{43}$ T. Woś, Wywłaszczenie i zwrot nieruchomości, Warszawa 1998; E. Lemańska, Przedawnienie roszczenia..., s. 83 .

${ }^{44}$ Wyrok NSA z 21 grudnia 2012 r., I ONP 31/10; także wyroki NSA: z 6 lutego 2009 r., I OSK 335/08; z 17 czerwca 2009 r., I OSK 874/08; z 9 kwietnia 2010 r., I OSK 821/09.

45 Wyrok NSA z 6 lutego 2009 r., I OSK 335/08.

${ }^{46}$ Z. Leoński, M. Szewczyk, M. Kruś, op. cit., s. 480.

47 Ibidem, s. 481-482.
} 
Ustęp 5 z kolei brzmi następująco:

Starosta, wykonujący zadanie z zakresu administracji rządowej, wydaje odrębną decyzję o odszkodowaniu:

1) $[\ldots$.$] ;$

2) na wniosek podmiotu realizującego cel publiczny lub właściciela wywłaszczonej nieruchomości;

3) gdy nastapiło pozbawienie praw do nieruchomości bez ustalenia odszkodowania, a obowiązujące przepisy przewidują jego ustalenie.

Sąy administracyjne potwierdzaja, że regulacja art. 129 ust. 5 pkt 2 i 3 u.g.n. dotyczy także stanów sprzed jej wejścia w życie, tj. sprzed 1 stycznia 1998 r. ${ }^{48}$

\section{KONKLUZJE}

Jak wskazano, stanowisko doktryny odnośnie do charakteru roszczenia o odszkodowanie za wywłaszczenie jest podzielone. Wydaje się jednak, że uprawnienie do dochodzenia roszczenia za wywłaszczenie jest publicznym prawem podmiotowym jednostki. W pojęciu publicznych praw podmiotowych mieszczą się bowiem uprawnienia podmiotowe wobec administracji publicznej, których treść jest co do zasady determinowana przez przepisy ustaw. Jak wyżej wykazano, cechą publicznych praw podmiotowych jest to, że nie ulegaja przedawnieniu, chyba że ustawa stanowi inaczej. Zatem konsekwencja przyjęcia administracyjnoprawnego charakteru przedmiotowego roszczenia jest brak przedawnienia tego typu roszczeń, o ile ustawa nie przewiduje wyjątku ${ }^{49}$.

Administracyjnoprawny charakter roszczenia o odszkodowanie z tytułu wywłaszczenia potwierdza bogate orzecznictwo i stanowisko doktryny. Chociaż kwestia ta wywoływała już kontrowersje w latach trzydziestych XX w., nie ulega wątpliwości, że na gruncie Prawa o postępowaniu wywłaszczeniowem z 1934 r. całe postępowanie wywłaszczeniowe należało w naszym ustawodawstwie do gałęzi prawa publicznego. Także Sąd Najwyższy ${ }^{50}$ opowiedział się za administracyjnoprawnym charakterem roszczenia odszkodowawczego na gruncie dekretu z 1949 r. Sąd Najwyższy uzasadnił swoje stanowisko przez wskazanie, że wywłaszczenie nastapiło na rzecz Państwa, a do jego dochodzenia wskazano tryb administracyjnoprawny. Także współcześnie Naczelny Sąd Administracyjny, orzekając o odszkodowaniu na podstawie u.g.n., opowiada się za administracyjnoprawnym charakterem roszczenia ${ }^{51}$. Odszkodowanie za wywłaszczenie jest nierozerwalnie związane z postępowaniem administra-

48 Wyroki NSA: z 16 maja 2013 r., I OSK 2311/11; z 4 października 2012 r., I OSK 1104/11; z 26 sierpnia 2014 r., I OSK 147/13; z 21 grudnia 2009 r., I OSK 1111/08; z 6 marca 2012 r., I OSK 397/11; wyrok WSA w Krakowie z 15 czerwca 2011 r., II SA/Kr 513/11; wyrok WSA w Lublinie z 23 października 2008 r., II SA/Lu 591/08; wyrok WSA w Rzeszowie z 28 października 2009 r., II SA/Rz 385/09; wyrok WSA w Lublinie z 11 października 2012 r., II SA/Lu 374/12.

${ }^{49}$ Z. Leoński, M. Szewczyk, M. Kruś, op. cit., s. 482.

${ }^{50}$ Orzeczenie SN z 7 maja 1960 r., III CR 812/59, niepubl.

51 Wyrok NSA z 25 lutego 2009 r., I OSK 460/08; podobnie wyrok NSA z 6 lutego 2009 r., I OSK 335/08. 
cyjnym głównym ${ }^{52}$, przez co należy rozumieć związek przyczynowo-skutkowy pomiędzy wywłaszczeniem i odszkodowaniem za nie (mimo dwóch odrębnych procedur).

Jednocześnie nie należy zapominać o kompensacyjnej i sprawiedliwościowej funkcji „słusznego” odszkodowania. Państwo powinno dawać gwarancję ochrony mienia swoich obywateli, a każde ograniczenie i zniesienie prawa własności (nawet te konieczne ze względów publicznych) nie powinno zostać przeprowadzone kosztem jednostek ${ }^{53}$.

\section{dr Maciej Kruś}

Uniwersytet im. Adama Mickiewicza w Poznaniu

mkrus@amu.edu.pl

\section{THE PUBLIC LAW NATURE OF COMPENSATION CLAIMS FOR EXPROPRIATION OF REAL ESTATE}

\section{Sum mary}

The qualification of compensation claims for expropriation of real estate to the public law sphere or the private law sphere raised many legal doubts in interwar Poland and has remained not fully resolved until the present date. This qualification is particularly relevant in view of the limitation period regarding the compensation claim. Under administrative law, contrary to the claims of a civil law character, there is no limitation of claims, unless the law provides otherwise.

In this article, some exemplary legislative acts that constitute the grounds for expropriation of real estate procedures and possible claims for compensation are analysed, starting from the law on expropriation proceedings contained in the ordinance of 1934, through post-war decrees and amendments, to the Act on Property Management currently in force. Further, on the basis of the decisions delivered by common courts and administrative courts as well as opinions of high standing legal scholars, the author attempts to justify his stance on the public law nature of compensation claims for expropriation of real estate.

${ }^{52}$ Postanowienie NSA z 15 stycznia 2014 r., I OZ 1247/13; tak też w postanowieniu NSA z 14 maja 2013 r., I OZ 357/13.

${ }^{53}$ F. Zadrowski, op. cit., s. 34-35. 
